\title{
Parotid Gland Non-Hodgkin Lymphoma
}

National Cancer Institute

\section{Source}

National Cancer Institute. Parotid Gland Non-Hodgkin Lymphoma. NCI Thesaurus. Code C5951.

A non-Hodgkin lymphoma that arises from the parotid gland. Representative examples include mucosa-associated lymphoid tissue lymphoma and diffuse large B-cell lymphoma. 